\title{
İşveren Markası Yönetimi Sürecinde İşe Alım Öncesi Dönem ve İşören Seçimi: Kavramsal Bir Değerlendirme

\author{
Pre-Recruitment Period and Employee Selection in Employer Brand \\ Management Process: A Conceptual Evaluation
}

\author{
Ebru GÖZEN \\ Ela Quality Resort Hotel - ANTALYA \\ İnsan Kaynakları ve Eğitim Müdür Yardımcısı \\ ebrugozen2306@gmail.com
}

\begin{abstract}
Özet
Günümüzde kendini sürekli olarak yenileyen teknolojik, sosyo-ekonomik ve kültürel değişiklikler işletmeleri sıkı bir rekabet ortamına sürüklemiştir. $\mathrm{Bu}$ rekabet ortamında varlıklarını sürdürebilmeleri doğru işgücünü bulma ve istihdam etme becerilerine bağlıdır. İşletmelerdeki insan kaynakları biriminin kalitesi ve başarısı da çoğunlukla işgören bulma sürecindeki başarısına bağlıdır. $\mathrm{Bu}$ süreç, diğer İK süreçlerinin de temelini oluşturmaktadır. İnsan kaynakları yazınında son yıllarda gündeme gelen işveren markası bileşenlerinden de bir tanesini işe alım öncesi dönem ve işgören seçimi uygulamaları oluşturmaktadır. Bu çalışmada da işe alım öncesi dönem ve işgören seçimi süreçleri işveren markası yönetimi perspektifinden sunulmuş olup, bu temelde gelecek araştırmacılara öneriler getirilmesi hedeflenen bu çalışma ile özellikle konuyla ilgili ülkemizde oldukça sınırlı olan literatüre de katkıda bulunulması açısından önemlidir.

Anahtar Kelimeler: İşveren markası yönetimi, işe alım öncesi dönem, işgören seçimi.

\section{Abstract}

Nowadays constantly renewing itself technological, socio-economic and cultural changes have dragged the companies to the tight competition. They can sustain their assets depends on finding the right labor and employment abilities. The quality and success of the human resources departments mostly depends on the process of finding employee. This process forms the basis of the other HR processes. One of the components of employer branding is Pre-Recruitment Period and Employee Selection. In this study, pre- recruitment and employee selection process is presented from the perspective of employer brand management. On this basis, it's targeted to make suggestions for future researchers. The literature on this subject is very limited in our country. So this study is important to contribute to the literature.
\end{abstract}

Key words: Employer brand management, pre-employment period, employee selection. 


\section{Giriş}

Gün geçtikçe artan küresel rekabet ortamında işletmeler, sürdürülebilir rekabet üstünlüğü elde edebilmek için işgörenlerin başlıca bir kaynak olduğunu kabul etmektedir. Çağdaş yönetim anlayışında örgütü başarılı ya da başarısız yapan koşulların, insan ve beklentilerine verilen önemle bağlantılı olduğu vurgulanmaktadır (Pelit ve Öztürk, 2010. S.44). Bir işletmenin fiziki yapısı, maddi kaynakları ne kadar iyi olursa olsun, eğer bu yapıyı çalıştırabilecek, maddi kaynakları etkin bir şekilde kullanabilecek insan kaynaklarına sahip değilse, amacını gerçekleştirmesi mümkün değildir. Yönetim alanındaki girişimciler, yöneticiler ve araştırmacılar da işgörenleri işletmelere rekabet avantaj1 getiren en önemli kaynak olarak kabul etmektedirler (Pelit vd., 2011. s.785). İnsan kaynaklarının işletmelerin stratejik bir bileşeni olması gerektiği da uzun zamandır üzerinde konuşulan bir konudur. Yakın geçmişe kadar ne yazık ki personel yönetimi ile insan kaynakları yönetimi kavramları birbiri yerine kullanılmaktaydı. Oysa ki bu iki kavram çok önemli noktalarda birbirinden ayrılmaktadır. Örneğin, personel yönetimi çalışanları "maliyet unsuru" olarak değerlendirirken, insan kaynakları "varlık ve sermaye" olarak algılar ve onların donanımlarını artırmaya çalışır. Günümüzde işletmelerin rekabetçi üstünlüklerini korumada taklit edilmesi zor olan kaynaklara, diğer bir ifadeyle donanımlı işgücüne sahip olması, onları elde tutması ve işletme hedefleri doğrultusunda kullanabilmesi kritik öneme sahiptir. Bir işletmeden sorumlu olan kişilerin /yöneticilerin belirledikleri amaçlara ulaşabilmeleri için yararlandıkları kaynaklar arasında en önemlisi ve en zor temin edileni şüphesiz insan kaynağıdır (Pelit, 2015. s.74). İşveren markası kapsamında da amaç mümkün olduğunca çok başvuru almak değil, doğru olanları almaktır (Melin, 2005. s.13). Bu nedenle rekabetçi üstünlük elde etmek ve bunu sürdürülebilir kılmak isteyen işletmeler işe alım öncesi dönem çalışmalarında işveren markası konusuna gereken önemi vermelidir.

İşveren markası, işletmelere kendilerini sahip oldukları pazarda mevcut işgörenlerine karşı işveren olarak, yeni adaylara karşı potansiyel işveren olarak, müşterilere karşı da hizmet sağlayıcı olarak tanımlamalarına odaklanmaktadır (Melin, 2005 , s. 9) ve işe alım öncesi dönem ve işgören seçimi, iş-özel hayat dengesi, kurum kültürü ve çevre, ürün/kurum markası gücü, ücret ve yan haklar ile çalışma ortamı gibi bir takım bileşenlerden oluşmaktadır. Bu bileşenler aynı zamanda insan kaynakları işlevidir. Bu çalışmada bir çok insan kaynakları işlevleri arasından işe alım öncesi dönem ve işgören seçimi süreci ele alınmıştır. Bu sürecin ele alınmasının nedeni, işe alım öncesi dönem ve işgören seçimi sürecinin diğer insan kaynakları uygulamalarının temelini oluşturmasından kaynaklanmaktadır. İşgören bulma ve seçme süreci sonunda birey iş için en uygun kişi olduğuna inanmakta ve işletme nezdinde değerli olduğunu düşünmektedir.

\section{2. İşe Alım Öncesi Dönem İnsan Kaynakları Uygulamaları}

İnsan kaynakları yönetimi, çalışma yaşamına ilişkin olarak tüm süreçlerde rol oynayan doğru sayıda ve nitelikte işgörenin planlanmasından itibaren, işe girme, oryantasyon, eğitim, kariyer yönetimi, sağlık ve güvenlik yönetimi, performans ve ücret yönetimi, çalışma ilişkilerinin düzenlenmesi gibi işlev ve faaliyetleri kapsayan bir işletme fonksiyonudur (Gürüz ve Yaylacı, 2004, s. 23).

Özellikle finans ve pazarlama gibi diğer işletme fonksiyonları ile karşılaştırıldığında, iş yaşamındaki rolünü meşrulaştırmak konusunda temel bazı problemler yaşamıştır (Martin vd., 2005, s. 76). Bu durumda, insan kaynakları yönetimi 
alanında hem tahmin yapabilmek hem de insan kaynaklarının organizasyonel işleyişe etkilerini anlayabilmek açısından kuramsal modellere ihtiyaç vardır. İnsan kaynakları yönetiminin stratejik yönetim sürecine entegre edilmesi ve stratejik insan kaynakları yönetiminin hem içeriksel hem de ilişkisel olarak çözümlenebilmesi açısından kaynak bağlılı̆̆1 kuramı, uygun kuramsal zemini sağlamaktadır. Bu kurama göre rekabetçi üstünlük, strateji ve işletmenin içsel kaynakları ile ilişkilendirilmektedir. Kullanılan anahtar kavram organizasyonel yetkinlik (core competency) kavramıdır. Kısacası, geleneksel stratejik analiz endüstri - çevre odaklıyken kaynak bağlılığı, perspektifi organizasyonun kendisine ve iç süreçlerine kaydırmıştır (Sayılar, 2004). Stratejik insan kaynakları yönetimine ilişkin araştırmaların büyük bir kısmı da, kaynak bağlılığ 1 kuramının getirdiği "rekabetçi üstünlük yaratan örgütsel bir kaynak olarak insan kaynağının" temel kabulünden hareket etmektedir. Bu içeriği itibariyle stratejik insan kaynakları yönetiminin temel problematiği, organizasyonel performansı istenen doğrultuda ve düzeyde geliştirecek bir insan kaynakları sisteminin nasıl tasarlanacağıdır. Bu noktadan itibaren de bu amaca yönelik olarak geliştirilen işveren markası çalışmaları gündeme gelmektedir. İşveren markası uygulamalarına başlamadan önce ise mevcut ve potansiyel insan kaynağı anlamında organizasyonel davranış ve kişisel psikoloji açısından da işletmenin sahip olduğu farklılıkların neleri vaat ettiği önemlidir. İşletmenin kimliği, değerleri, politikaları, davranışları ve sistemi, işletmenin insan kaynağ ile bütünleşerek işletmenin sahip olduğu işveren markasının karakterini ortaya koymaktadır (Bodderas vd., 2010, s. 5). İnsan kaynakları yönetiminin işe alım öncesi dönemdeki işlevleri de şu şekilde açıklanabilmektedir (Gümüş, 2005);

- İş analizlerinin yapılması: İşe alım öncesi dönemde iş analizlerinin doğru bir şekilde yapılması önem arz etmektedir. İş analizi, bir işletmenin yaptığı işler ile ilgili bilgileri toplama, işleri detaylı olarak inceleme, analiz etme ve diğer insan kaynakları fonksiyonları için temel oluşturma faaliyetidir. İş analizi, seçme sürecinde de altyapı işlevi görmektedir. Eğitim programlarının içeriğine de etki etmekte ayrıca, ücretleme, performans değerleme, personel planlaması ve çalışma ilişkilerini geliştirme, iş analizlerinin yardımcı olduğu diğer insan kaynakları süreçleridir.

- İnsan kaynakları planlaması: İşe alım öncesi dönemde işletme gereksinimlerine uygun şekilde yapılması gereken ikinci konu doğru insan kaynakları planlamasıdır. İnsan kaynakları planlaması, işletmenin gelecekte ihtiyaç duyacağı personelin nitelik ve nicelik açısından önceden belirlenmesi ve bu ihtiyacın nasıl ve ne derecede karşılanabileceği faaliyetleridir.

- İş başvurularının alınması: İnsan kaynaklarını bulma aşamasında aday havuzu oluşturulduktan ve işletme için gereksiz adaylar elendikten sonra insan kaynakları seçimi aşamasına geçilir. İnsan kaynaklarını bulma süreci adayların işe başvurması ile sona erer, başvurunun yapılması ile beraber insan kaynakları seçim süreci başlar.

İnsan kaynakları seçiminin yapılması: İnsan kaynakları seçimi; insan kaynakları bulma sürecinde oluşturulmuş olan insan kaynağı havuzu içinden işin gerektirdiği niteliklere sahip en uygun olanını belirleme faaliyetidir. İnsan kaynaklarını bulma ile seçimi süreci birbiri ile doğrudan bağlantılıdır ve doğru personelin doğru işe yerleştirilebilmesi insan kaynakları bulma sürecinin sağlıklı işlemesine bağlıdır.

Tüm bu faaliyetler gerçekleştirilirken aynı veya benzer işi yapan rakiplerden farklılaşabilmek, nitelikli adayları işletmeye çekebilmek için de işveren olarak marka olma çalışmalarına önem verilmesi gerekmektedir. 


\section{3. İşveren Markası Yönetimi}

İşe alım öncesi dönemde adaylar, bir işletmenin kültürü, işgörenleri, vizyonu, misyonu, çalışmak için iyi bir yer olup olmadığı ile ilgili bilgileri kurumsal web sitelerinden öğrenmektedir (Oğuz, 2012, s. 17). Amerikalı insan kaynakları işletmesi Robert Half' 'n yaptığı araştırmaya göre; tüm dünyada İK uzmanlarının \%18'i, ABD'de $\%$ 65'i, Türkiye'de ise \%35'i eleman aramak için sosyal medyayı kullanmaktadır (Mengi, 2012). Özellikle genç kuşağın işveren tercihlerini büyük ölçüde "sosyal ağlar" etkilemektedir. Nitelikli insan kaynağı temininde internetin önemini kavrayan bazı işletmeler ayrı bir kariyer sayfası oluşturma yoluna da gitmektedir (Baş, 2011). Aslına bakılırsa, işletmeler farkında olsun ya da olmasın iyi veya kötü bir işveren markasına sahiplerdir. Önemli olan bunu doğru şekilde yönetebilmektir.

İşveren markasının yönetimi sürecinden bahsetmeden önce, işveren markasının tanımını yapmakta yarar vardır. İşveren markasının çeşitli kaynaklarda yapılmış olan tanımlarını Tablo 1'de görmek mümkündür.

\section{Tablo 1. İşveren Markası Tanımları}

\begin{tabular}{|c|c|c|}
\hline & Tanım & Kaynak \\
\hline & $\begin{array}{l}\text { İşletmenin çalışmak istenilen yer olmak için mevcut ve potansiyel } \\
\text { işgörenleri ile iletişim kurma gayretlerinin toplamıdır. }\end{array}$ & (Berthon vd. 2005) \\
\hline & $\begin{array}{l}\text { İşletmenin mevcut ve potansiyel işgörenlerini cezbetmek, motive etmek ve } \\
\text { elde tutmak amacına yönelik olarak belirlediği değer, sistem, politika ve } \\
\text { uygulamalardır. }\end{array}$ & (Erdemir, 2007) \\
\hline & $\begin{array}{l}\text { Bir işletmenin kendisini işveren olarak farklı ve çekici kılan özelliklerine } \\
\text { yönelik kesin bir algı oluşturabilmek için işletmenin içinde ve dışında } \\
\text { yürüttüğü çabalardır. }\end{array}$ & $\begin{array}{l}\text { (Backhaus ve } \\
\text { Tikoo, 2004) }\end{array}$ \\
\hline & $\begin{array}{l}\text { Aynı zamanda, batılı bir kavram olup “önde gelen işveren” (employer of } \\
\text { choice) olabilmek için stratejik görevin tanımlanmasıdır. }\end{array}$ & (Kapoor, 2010) \\
\hline & $\begin{array}{l}\text { İşveren tarafından sunulan fonksiyonel, ekonomik ve psikolojik yararlar } \\
\text { paketidir. }\end{array}$ & (Baş, 2011) \\
\hline$\frac{1}{2}$ & $\begin{array}{l}\text { Tercih edilen işletme olmak, işletmelerin kendilerini "çalışılacak en iyi } \\
\text { yer" olarak diğer işletmelerle karşılaştırabilecekleri bilinçli bir iş } \\
\text { stratejisidir. }\end{array}$ & (Martin vd., 2005). \\
\hline Z & $\begin{array}{l}\text { İşletme tarafından belirlenen ve işe alım ile sağlanan fonksiyonel, } \\
\text { ekonomik ve psikolojik faydalar bütünüdür. }\end{array}$ & $\begin{array}{l}\text { (Ambler ve } \\
\text { Barrow, 1996) }\end{array}$ \\
\hline 2 & İşletme ve işgörenleri arasındaki iki yönlü anlaşmadır. & (Rosethorn, 2009) \\
\hline & $\begin{array}{l}\text { İşletmelerin mevcut ve potansiyel işgörenlerine çekici görünmek için } \\
\text { gerçekleştirdikleri faaliyetlerdir. }\end{array}$ & (Bach, 2005) \\
\hline & $\begin{array}{l}\text { Mevcut işgörenlerin, potansiyel işgörenlerin ve paydaşların algılamalarını } \\
\text { ve farkındalığını yöneten hedeflenmiş, uzun dönemli bir stratejidir. }\end{array}$ & (Sullivan, 2004) \\
\hline & $\begin{array}{l}\text { İşveren markası, mevcut ve potansiyel işgörenlerin işletmenin çalışmak } \\
\text { için harika bir yer olduğu ile ilgili algısını belirten bir kavramdır. }\end{array}$ & (Duc/To, 2013) \\
\hline & $\begin{array}{l}\text { İşveren markası mevcut ve potansiyel işgörenlerin, ilgili paydaşların belirli } \\
\text { bir işletmeye yönelik algılarını ve farkındalıklarını yönetmek için } \\
\text { hedeflenen uzun soluklu bir stratejidir. }\end{array}$ & $\begin{array}{l}\text { (Katoen ve } \\
\text { Macioschek, 2007) }\end{array}$ \\
\hline & $\begin{array}{l}\text { İşveren markası, işletmeyi ayırt eden -genellikle maddi olmayan- nitelikler } \\
\text { ve özellikler dizisidir. }\end{array}$ & $\begin{array}{l}\text { (Walker ve } \\
\text { Higgins, 2007) }\end{array}$ \\
\hline & $\begin{array}{l}\text { İşletmenin mevcut ve potansiyel işgörenlerinin gözündeki imajıdır ve } \\
\text { tüketici markası ile karıştırılmamalıdır. }\end{array}$ & $\begin{array}{l}\text { (Kimpakorn ve } \\
\text { Tocquer, 2009) }\end{array}$ \\
\hline
\end{tabular}


Tablo 1.'de işveren markası ile ilgili tanımlara bakıldığında şu noktalar dikkate değerdir;

- Çalışmak istenilen bir yer olma,

- İşgörenler için değer ifade etme ve çekici olma,

- Değer, sistem, politika ve uygulamalar bütünü olma,

- İşlevsel, ekonomik ve psikolojik faydalar paketi sunma ve

- Diğer işletmeler karşısında rekabet gücünü artıran bir araç olma.

Buraya kadar sıralanan unsurlar dişında bütün işletmelerde olmasa da pek çoğunda verilen iş ilanlarındaki değişimler, işletmeyi tanıtan videolar, işletmeye ait kariyer sitelerinin oluşturulması, lise ve üniversitelerde düzenlenen kariyer günleri, işletmelerin her geçen gün biraz daha fazla sosyal medyada yer almaları ve bu kanallardan işgören arayışında bulunmaları aslında işletmelerin işe alım öncesi dönemde gerçekleştirdikleri işveren markası uygulamalarıdır.

İşe alım çalışmaları açısından işveren markası perspektifinden yaklaşıldığında ise, unutulmaması gereken noktanın işveren markası yönetiminin işe alım pazarlaması olmadığıdır. İşveren marka yönetimi insan kaynakları departmanının kaynaktan ziyade insana odaklandığı bütünsel projelerdir. İşletmelerde işe alımdan sorumlu departman insan kaynakları olmasına rağmen konu işveren markası olduğunda sorumlu departmanın hangisi / hangileri olacağı da tartışma konusu olmaktadır. Employer Brand International'ın 2011'de yaptığı çalışma sonucunda işveren markası yönetiminden hangi departmanın/departmanların sorumlu olabileceği Şekil 1'de görülmektedir.

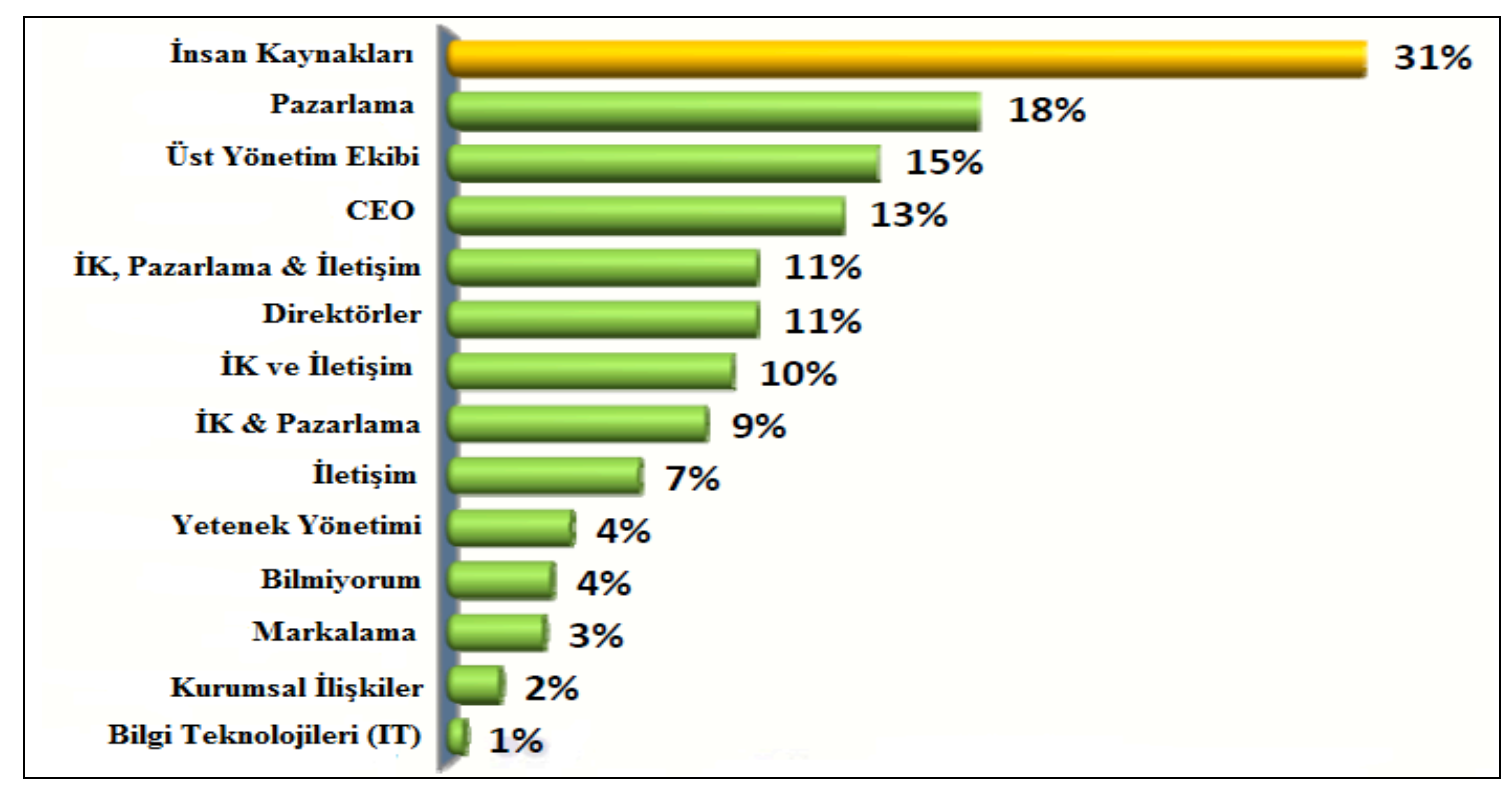

Şekil 1. İşveren Markası Yönetiminden Sorumlu Departman / Departmanlar (Minchington, 2014).

Şekil 1'den de anlaşılacağı üzere, İnsan Kaynakları Departmanı bu konudan sorumlu ana departman olarak görülmektedir. İşveren markası kavramı, insan kaynakları yönetimi alanında oldukça yakın zamanda yükselmiş ve pazarlama ilkelerinin insan kaynakları yönetimi alanına uygulanmasıyla ortaya çıkmış (Ong, 2011, s. 1089) bir kavram olsa da 2011 yılında yapılan bu çalışma kurumsal ve tüketici markalarının geleneksel sorumlusu olan pazarlama departmanının işveren markası yönetiminden sadece işletmelerin \%18'inde sorumlu olduğunu göstermektedir. 
Employer Brand International'ın 2009 yılında yaptıkları aynı çalışma sonuçlarında yönetim ekibi $\% 2$ ve CEO \%1 sorumlu olarak görülmekteydi. Bu da bizlere günümüzde işletmelerde işveren markalaşmasına daha stratejik uygulamalar konusunda artış olduğunu göstermektedir (Minchington, 2014).

İşveren markasının oluşturulması ve yönetilmesi bu işi profesyonel anlamda yapan işletmelerde işveren markası müdürü/yöneticisi unvanına sahip kişiler tarafından yürütülmektedir. Minchington (2010 b) 2006' da "Your Employer Brand attract-engageretain" adlı kitabını yayınladığında İşveren Markası Yöneticisi kavramının neredeyse duyulmadığını, bugün ise Nike, Ernst\&Young, United Health Group, Vestas Wind Systems, Starbucks, IBM, Ahold, E.ON, Deloitte, Nordea, DONG Energy, HP ve Deutsche Bank gibi işletmelerin işveren markası yöneticileri ile işveren markalarını geliştirmeye odaklandıklarını belirtmektedir. Bu konuya Türkiye'den bir örnek vermek gerekirse Türkiye İş Bankası'nda işveren markası çalışmalarını İnsan Kaynakları İletişimi Birimi yürütmektedir ve İnsan Kaynakları İletişimi Birimi, İnsan Kaynakları Yönetimi bölümüne bağlı olarak çalışmaktadır (Öksüz, 2012, s. 15).

Minchington (2014), işveren markası yöneticileri ile yaptı̆̆ı görüşmeler sonucunda aşağıdaki konuların bu yöneticileri işveren markasının evrimine katkıda bulunan ve kendilerini bu konuda üst seviyede bulunmasını sağlayan yetkinlikler olduğunu vurgulamaktadır;

- Stratejik düşünme yeteneği

- Üst düzey yetkilileri etkileyebilme yeteneği

- İşveren markalaşmasına küresel perfpektif yaklaşımı

- Ülkesi dışındaki en iyi işveren markası uygulamalarını seyahat ederek ve paylaşarak bir işletme elçisi rolünü benimsemesi

- İşveren markası paydaşları küresel ağını kurma ve geliştirme yeteneği

- Uyumlu bir işveren markası stratejisi sunmak için etkin bir şekilde iç ve diş takımlar oluşturma yeteneği.

Minchington (2014) tarafından yapılan çalışmanın bir diğer önemli sonucu ise Tablo 2.'de görülmektedir.

Tablo 2. Bölgesel Verilere Göre İşveren Markasından Sorumlu Departmanlar (İlk 3 Yanıt)

\begin{tabular}{|l|c|c|c|c|}
\hline & Avustralya & Avrupa / UK & Yeni Zelanda & USA / Kanada \\
\hline İnsan Kaynakları & 1 & 1 & 1 & 1 \\
\hline Pazarlama & 2 & 2 & 3 & $*$ \\
\hline Üst Yönetim Ekibi & $*$ & $*$ & 2 & $*$ \\
\hline CEO & 3 & $*$ & $*$ & $*$ \\
\hline Direktörler & $*$ & 3 & $*$ & 3 \\
\hline İK, Pazarlama \& İletişim & $*$ & 3 & $*$ & $*$ \\
\hline Yetenek Yönetimi & $*$ & $*$ & $*$ & $*$ \\
\hline Markalama & $*$ & $*$ & & $*$ \\
\hline
\end{tabular}

Kaynak: Minchington, 2014. 


\begin{tabular}{|l|c|c|c|c|c|c|c|c|}
\hline & Asya & Polonya & Rusya & $\begin{array}{c}\text { Güney } \\
\text { Afrika }\end{array}$ & $\begin{array}{c}\text { Güney } \\
\text { Amerika }\end{array}$ & Türkiye & BAE & Ukrayna \\
\hline İnsan Kaynakları & 1 & 1 & $*$ & 1 & 1 & 1 & 1 & $*$ \\
\hline Pazarlama & $*$ & 2 & 3 & $*$ & 3 & 3 & 2 & 1 \\
\hline Üst Yönetim Ekibi & $*$ & $*$ & 1 & 3 & $*$ & $*$ & $*$ & 2 \\
\hline CEO & $*$ & $*$ & $*$ & 2 & $*$ & $*$ & 2 & 2 \\
\hline Direktörler & $*$ & $*$ & $*$ & 3 & 2 & $*$ & 2 & 2 \\
\hline İK, Pazarlama \& İletişim & 2 & 3 & $*$ & $*$ & $*$ & $*$ & $*$ & $*$ \\
\hline İK \& İletişim & 3 & 2 & $*$ & $*$ & $*$ & 2 & 2 & 3 \\
\hline İK \& Pazarlama & $*$ & $*$ & 2 & $*$ & $*$ & $*$ & $*$ & $*$ \\
\hline İletişim & 2 & $*$ & $*$ & $*$ & $*$ & $*$ & 2 & $*$ \\
\hline Yetenek Yönetimi & $*$ & 3 & $*$ & $*$ & $*$ & $*$ & 2 & $*$ \\
\hline Markalama & $*$ & $*$ & $*$ & $*$ & 3 & $*$ & $*$ & $*$ \\
\hline
\end{tabular}

Tablo 2'de ilgi çeken nokta Rusya ve Ukrayna hariç tüm bölgelerde insan kaynakları fonksiyonunun işveren markası stratejisinin ana yöneticisi olduğudur. Çalışmada bunun ana nedeni olarak işveren markası kavramının bu bölgedeki işletmeler için yeni olduğu ve insan kaynakları işlevinin ABD, UK, Avustralya gibi gelişmiş pazarlardaki ile aynı etki ve profile sahip olmayışı gösterilmektedir.

İşletmelerde hangi birim tarafından yönetiliyor olursa olsun işveren markası çalışmalarının işe yarar olabilmesi için en başından bütün stratejinin bu çerçevede oluşturulması gerekmektedir. Potansiyel işgörenlerin zihninde ilk izlenimlerin oluşturulduğu işe alım öncesi dönem ve işgören seçimi aşamalarında işveren markası yönetimi standartlarının oluşturulmuş olması gerekmektedir.

\section{4. İşe Alım Öncesi Dönem İşveren Markası Uygulamaları}

İnsan kaynakları yönetimi, çalışma yaşamına ilişkin olarak tüm süreçlerde rol oynayan doğru sayıda ve nitelikte işgörenin planlanmasından itibaren, işe girme, oryantasyon, eğitim, kariyer yönetimi, sağlık ve güvenlik yönetimi, performans ve ücret yönetimi, çalışma ilişkilerinin düzenlenmesi gibi işlev ve faaliyetleri kapsayan bir yönetim fonksiyonudur (Gürüz ve Yaylac1, 2004, s. 23). Bu fonksiyonlar arasında işe alma sürecinin başarısı, öncelikle hazırlık çalışmaları olan insan kaynakları planlaması ve iş analizlerinin doğru yapılmış olmasına bağlıdır. Hangi iş için hangi nitelik ve sayıda insan kaynağına, hangi zamanda ihtiyacı olduğunu çeşitli yöntemlerle belirlemiş olan bir işletme, işe alma sürecinin asıl faaliyetleri olan işgören bulma ve seçmeye yönelecektir (Erdemir, 2007, s. 7).

Türkiye'de insan kaynakları yazınında yeni bir kavram olarak son yıllarda yerini alan işveren markası insan kaynakları yönetimi açısından üç aşamada incelenebilmektedir (Backhous ve Tikoo, 2004, s. 502);

1. İşletme somut bir değer önerisi geliştirmektedir. Değer önerisi geliştirilmesini takiben, değer önerisini potansiyel işgörenlerine, istihdam ajanslarına, danışmanlarına vb paydaşlarına pazarlamaktadır, 
2. İşveren markalaşmasının dış pazarlaması temel olarak hedef popülasyonu çekecek şekilde ve aynı zamanda ürün ve kurumsal markaları destekleyecek ve geliştirecek şekilde tasarlanmaktadır ve,

3. İçsel pazarlama, işveren markasının üçüncü adımıdır. Amacı, örgütsel değerler ve amaçlar bütününe bağlı kalarak işgücünü geliştirmektir.

$\mathrm{Bu}$ aşamaları açacak olursak, ilk yapılması gerekenin somut, gerçekleştirilebilir bir değer önerisi (vaad) geliştirilmesi gerekliliğidir. Bu şekilde işletme işe alım öncesi dönemde potansiyel işgörenlerine tercih edilmeleri durumunda neler sunabileceğini söylemiş olmaktadır. Sonrasında dış pazarlama çalışmalarında da işletmenin sadece kurum olarak değil işveren olarak da konumlandırılması gerekmektedir. Üçüncü ve son aşamada ise, içsel pazarlama gelmektedir. İşletme oluşturmak istediği işveren markasını önce mevcut çalışanlarına benimsetmelidir. Bunun nedeni mevcut çalışanların dişardaki potansiyel adayları etkileyebilmesidir. Ancak ne yazık ki halen işletmelerin pek çoğu bu aşamaları göz ardı etmektedir. Dünyanın önde gelen İnsan Kaynakları stratejistlerinden biri olarak tanınan San Francisco Devlet Üniversitesi'nden Dr. John Sullivan 2006 yılında yayınlanan makalelerinden birinde Türkiye'nin ciddi anlamda nitelikli bir İK potansiyeline sahip olduğuna, ancak ülkedeki işletmelerin işveren markalamasından bihaber olduklarına dikkat çekmektedir (Bloomberg Businessweek Türkiye, 2010, s. 50). Böyle olunca da işe alım öncesi dönemde işveren markası uygulamalarına önem verilmediği görülmektedir. Oysa ki işletmenin işveren imajı ile ilgili işe alım öncesi dönemdeki izlenimler, adayları işletmeye çekmek için güçlü göstergelerdir (Lievens ve Highhouse 2003). Ancak bununla birlikte, halen işveren imajının iş arayanların işletmeye katılma niyetlerini nasıl etkilediği ile ilgili anlayış eksikliği bulunmaktadır (Baum ve Kabst, 2013, s. 175).

İşveren imajı, işe alım öncesi işgören açısından önemli bir konudur. Bunun nedeni, işveren markasının potansiyel işgören pazarının zihninde işyerini çalışmak için harika bir yer olarak inşa etmesinden kaynaklanmaktadır (Alnıaçık ve Alnıç̧ık, 2012, s. 1337). İşveren markası imajı, işletmeye başvuruda bulunan kişilerin kendisi ile mülakat yapan kişinin davranışları ile ilgili algısını (iş ve örgütsel özellikler gibi) da olumlu etkilemektedir (Baum ve Kabst, 2013, s. 176). Bu açıdan bakıldığında işletme işveren imajının temel bileşenleri; işgörene yönelik elde tutma çabaları, reklam ve tanıtım, çalışma ortamının fiziksel özellikleri, yaygınlık, müşteri memnuniyeti, işyerinin coğrafi konumu, ücretler, ürün imajı, adayların sektörle ilgili deneyimleri, söylentiler, saygınlık, çalışma yoğunluğu, iş arkadaşları, çalışma saatleri ve iş çeşitliliğidir (Erdemir, 2007, s. 84). İşe alım öncesi dönemdeki uygulamalar aynı zamanda işveren marka imajının iki boyutu sayesinde (işletmeye karşı genel tutum ve işin algılanan öznitelikleri) eğilimler ve kararlarla da dolaylı yoldan ilgilidir (Berthon vd., 2005, s. 154).

İşveren markası yönetimi, işe alım sürecinin etkinliğini de son derece artırmaktadır. Bu etkinliğin arttığını ise belli göstergelerle anlamak mümkündür (Baş, 2011, s. 124):

- $\quad$ İşe yeni alınan işgörenlerin performansı,

- İşe yeni alınanların başarısızlık oranları,

- Yeni işe alınanların işten ayrılma oranları,

- İşgören alımının zamanında tamamlanma oranı, 
- Yeni işe alınanları iş tatmini düzeyi,

- Rakip işletmelere transfer edilenlerle/alınanların oranı,

- $\quad$ Nitelik, yetenek eksikliği yüzünden yaşanan proje gecikmeleri,

- $\quad \mathrm{Al} /$ Ver oran1,

- $\quad$ Proje Gecikmeleri,

- Yeni işe alınanların oryantasyon süreleri,

- Yeni işe alınan adaylardan verim sağlayana kadar geçen süre ve azalış/artış.

- $\quad$ İşveren markası yönetimi süreciyle birlikte tanıtım ve ilan giderlerindeki

Duc/To (2013) da işe alım sürecinde işveren markasının yerini Şekil 2'deki gibi tanımlamıştır.

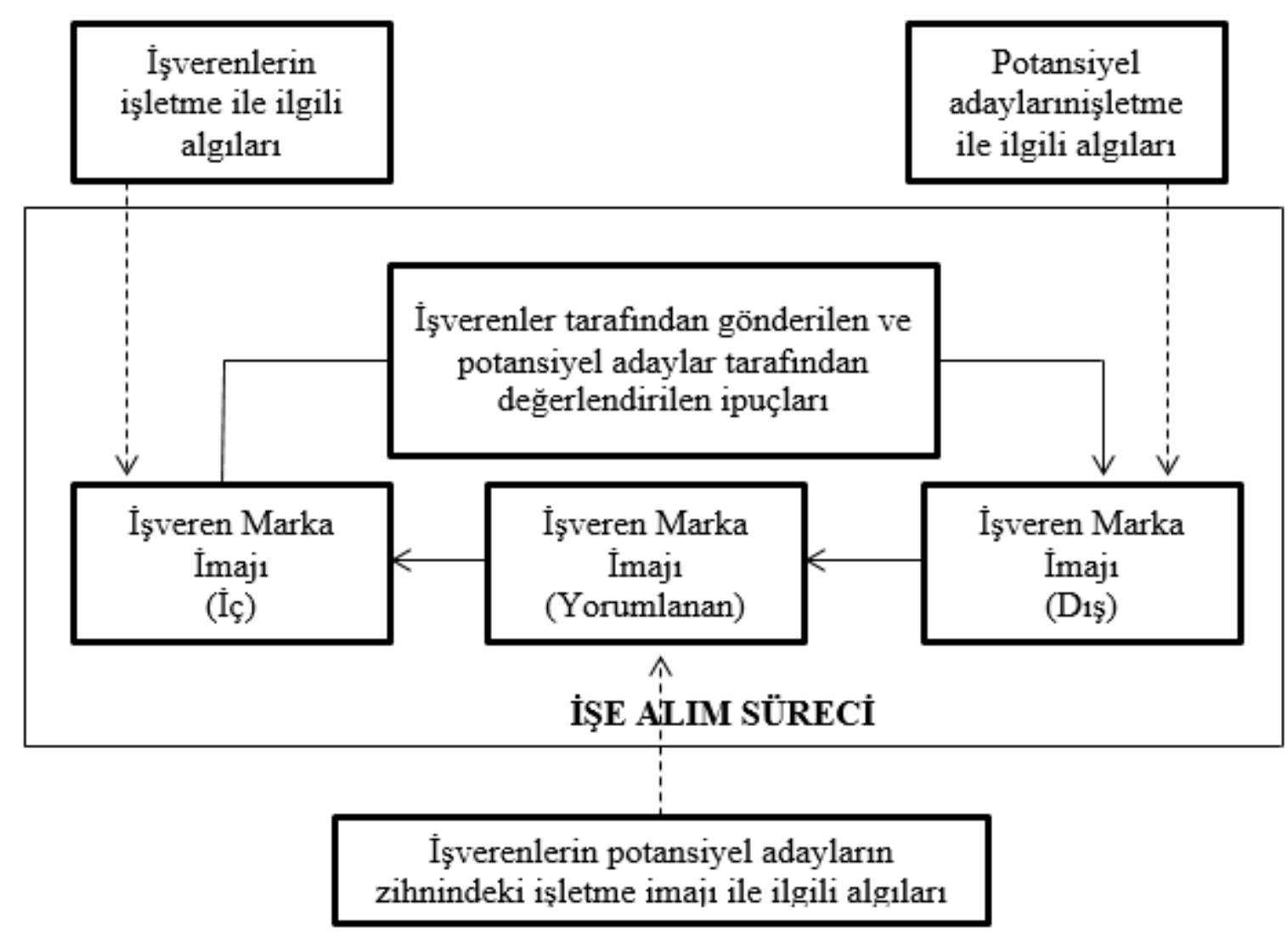

Şekil 2. İşe Alım Sürecinde İşveren Markası (Duc/To,2013, s. 15)

Şekil 2'den de anlaşılacağı üzere pazarlama yazınında da belirtildiği gibi markanın imajı içerden ve dışardan farklı algılanmaktadır. Bir yanda işverenlerin işletme ile ilgili algıları yer alırken diğer yanda potansiyel adayların işletme ile ilgili algıları yer almaktadır. İşletmenin dişardaki işveren marka imajı potansiyel adayların işletme ile ilgili algılarını etkilerken, içerdeki işveren marka imajı işverenlerin işletme 
ile ilgili algılarını etkilemektedir. Bu durum, işletmenin işveren markasının da mevcut ve potansiyel işgörenler tarafından da farklı algılandığının göstergesi olabilmektedir.

Konuya işe alım noktasından bakıldığında, hangi özeliklerin işletmenin karakteristiği olarak tanımlandığı da önemlidir. Örneğin, işletmede yeni olan işgörenler özellikle büyük eğitim firsatları ararlarken mevcut işgörenler bu fırsatlara sahip olunduğunu tanımlamadıklarında ortada açık bir şekilde uyuşmazlık çıkmaktadır. İşletmenin ihtiyacı olan yetenekleri istihdam etmek için bu ve benzeri konuları da belirtmesi gerekmektedir (Melin, 2005). Örneğin, Southwest Airlines, Starbucks gibi işletmeler doğru insanı istihdam etmeleri ve eğitmeleri ile bilinmektedirler. Starbucks'ın web sitesinde, işgörenleri (partner olarak adlandırılmakta) arasındaki mükemmellik değerleri, diğer işgörenlere karşı (tıpkı misafirlere olduğu gibi) saygılı davranışlar ve sosyal sorumluluğa yapılan ithaf gibi Starbucks değerleri yer almaktadır ve Starbucks'ta şuna inanılmaktadır "bu değerleri paylaşan kişiler uygun şekilde eğitildiğinde ve geliştirildiğinde arzu edilen marka imajını Starbucks müşterilerine iletecektir (Mangold ve Miles, 2007, s. 425). Unilever de yeni mezunların işe alım sürecinde son derece titiz davranmaktadır. Üniversitede iletişim halinde oldukları son sınıf öğrencileri www.unilever.com.tr/careers üzerinden MT (management trainee-yönetici adayı) başvuru formunu doldurarak MT işe alım sürecine girmiş olmaktadır. Yetkinlik bazlı sorular içeren bu başvuru formları teker teker okunup puanlanmakta ve formu geçen adaylar kısa listelere alınıp, yetkinlik bazlı tek bir mülakata tabi tutulmaktadırlar. Form ve mülakattan sonraki üçüncü ve son aşama "Selection Board" denilen form ve mülakatlardan seçilen en başarılı altı adayın katılımıyla gerçekleşen değerlendirme merkezidir. Üst düzey Unilever yöneticilerinin adayları gözlemlediği değerlendirme merkezinde, olumlu adaylara iş teklifi yapılmaktadır (Sakarya, 2012, s. 58).

İşveren markası yönetimi kapsamında Minchington (2010 a)'un yaptığ araştırma sonucu, işe alım ve işe alım mesajları ile ilgili elde ettiği bulgular da aşağıdaki gibidir;

1. İşe alım çalışmalarının planlanmasında kadın ve erkeklerle iletişim kurulurken farklı açılara odaklanılması gerektiği unutulmamalıdır. Esnek çalışma şartları teklifi ve samimi bir iş ortamı erkeklere kıyasla kadınlar için daha etkileyici bir işyeri seçimi kriteridir. Erkekler, açıkça tanımlanmış misyon, inovasyon kültürü ve yüksek düzeyde müşteri hizmeti sunan işletmelerden etkilenmektedirler. Randstad Award (2012)'de işyerinin elverişli konumu kadınlar için çok daha önemliyken, son teknolojinin kullanılıyor olması erkekler için daha önemli bulunmuştur,

2. İnsanlar farklı kültürlerde yetişmişlerdir. $\mathrm{Bu}$ nedenle, hayatta da farklı şeylere değer vermektedirler. Küresel bir işe alım kampanyası planlarken de bu akılda tutulmalıdır. Örneğin; çalışma esnekliği, Avrupalı işgörenlerden ziyade Amerika, Kanada ve Avustralya'lı işgörenlerle ilgili olmalıdır. Diğer kültürlerle ilgili varsayımlarda bulunulmamalı, onlar için neyin önemli olduğu anlaşılmaya çalışılmalıdır,

3. İnsanlar yaşlarına göre değişmektedirler. İnsanlar 55 yaş üstünde olduğunda, işletmelerinin kurumsal sosyal sorumluluk aktivitelerinin veya müşteri ilişkilerinin topluma olan etkisine odaklanmaktadırlar. Diğer taraftan, güçlü liderlik ve performans yönetiminden çok daha az etkilenmektedirler. Randstad Award (2012)'de güçlü bir yönetimin yaş ortalaması yüksek kişiler için daha önemli olduğu, son teknoloji kullanımının ise yaş ortalaması daha düşük kişiler için daha önemli olduğu görülmüştür, 
4. Pek çok işe alım kampanyası üniversite mezunları ve temel seviyedeki pozisyonlara odaklanmaktadır. Bu kişiler, henüz işten tam olarak ne beklediklerini bilmedikleri için işe alım reklamlarındaki etkileyici kelimelerden ziyade iyi bir kariyer başlangıcı aramaktadırlar. İşveren seçerken liderlik, stratejik amaç veya müşteri ilişkilerine çok fazla odaklanmamaları aslında sürpriz değildir. Bu kişiler daha çok, gündelik yönlerine; yeni iş arkadaşlarına (çalışma ortamı), açıkça belirtilmiş kariyer basamaklarına ve küresel bakış açısına odaklanmaktadırlar. $\mathrm{Bu}$ nedenle işletmelerde sadece insan kaynakları yönetiminin değil, pazarlama ve kurumsal iletişim birimlerinin birbiri ile sıkı işbirliği içerisinde olması gerekir (Öksüz, 2012, s. 23). Randstad Award (2012)'de yüksek eğitim seviyesine sahip kişiler için güçlü imaj / güçlü değerler unsurunun daha önemli olduğu, eğitim seviyesi daha düşük bireyler için ise iyi eğitim olanaklarının daha önemli olduğu görülmüştür,

5. Belirli beklentiler sektör türüne göre oluşturulmalıdır. Özel sektöre göre, devlette veya kar amacı gütmeyen kuruluşlarda çalışmaya yönlendirilen kişiler farklı konulara değer vermektedirler ve bu beklentilerini karşılayan işletmeleri tercih etmektedirler,

6. Araştırma, özel işletme işgörenlerinin liderlik, performansa göre ödül ve küresel perspektife kamu ve kar amacı gütmeyen kuruluşlarda işgörenlere göre daha fazla değer verdiklerini göstermektedir. Diğer taraftan, kamu işgörenleri esneklik ve kurumsal sosyal sorumluluğa değer vermektedir. Bu örnekler, farklı türdeki örgütlerin genelde farklı profilde insanları istihdam ettiğini göstermektedir,

7. Farklı pozisyon seviyeleri farklı işe alım stratejisi gerekmektedir. Farklı pozisyon seviyeleri farklı pazar segmentleri gibidir. Farklı özellikleri, ihtiyaçları, beklentileri en önemlisi farklı amaçları vardır. İşletmeler işgörenlerini anlamalı ve bu amaçlarını gerçekleştirmeleri için onlara yardımcı olmalıdır,

8. İnsanlar, iş tekliflerini kariyer basamaklarında tek başına ilerledikleri için farklı görmektedirler. Temel seviyede veya yönetici pozisyonunda işgörenler işletmenin özel hayat - iş hayatı dengesini nasıl etkilediğine odaklanacaktır,

9. Eğer işletmenin sıkıntısı işgörenleri elde tutmak konusunda ise, iş tekliflerinin orada işgörenlerin görev süresine göre değişip değişmediğine odaklanılmalıdır. En sık rastlanan hata, kişiye istihdam yaşam döngüsü boyunca her seferinde aynı faydaları sunmaktır. İşgörenlerin beklentileri, aynı işletmede çalışma sürelerinin uzunluğuna bağlı olarak değişmektedir. İşveren markası çalışmaları bu açıdan işletmelere ve işgörenlere değer katmaktadır. Profesyonelleşmiş, kurumsallaşmayı sağlamış, modern ve demokratik insan kaynakları yönetiminin bir sonucu olan ve insanı "değer" unsuru olarak ele alan bir yaklaşımdır (Ören ve Yüksel, 2012, s. 48),

10. İşgörenlerin beklentilerinin zamanla değişimi ile ilgili bir model çerçevesi geliştirilebilir. Yöneticiler, işe alım kampanyası boyunca açıkça belirtilmiş vaatleri iletme konusunda geliştirilebilir ve donatılabilirler ve

11. İnsanlar medeni durumlarına göre de önem verdikleri konularda ayrılabilmektedirler. Örneğin, uzun dönem iş güvencesi ailesi ile yaşayan ve evli fakat çocuğu olmayan kişiler için daha önemliyken, finansal açıdan büyüklük evli ve çocuklularda daha fazla önem arz etmektedir (Randstad Award, 2012). 
Linkedin'in Ekim 2011'de ABD, İngiltere, Avustralya, Kanada, Hollanda ve Hindistan'da yaptığ 1 araştırmanın paralelinde Türkiye'de gerçekleştirilen 2012 İşe Alım Araştırma Raporu'na göre Türkiye - ABD ve Hindistan işe alım süreçleri ile ilgili bir takım bilgiler Şekil 3'de yer almaktadır.

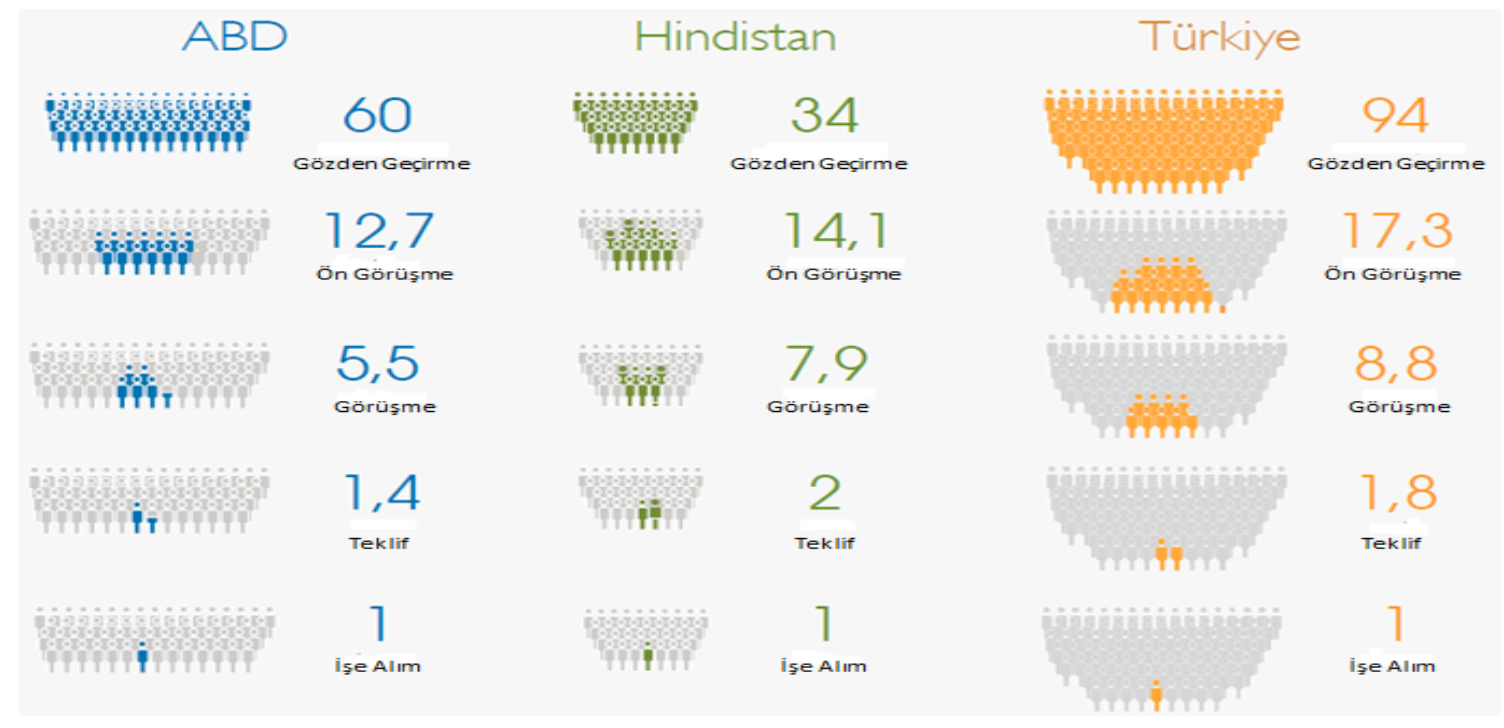

Şekil 3. Bir Kişiyi İşe Almak İçin Görüşülen Aday Sayısı (İşe Alım Araştırma Raporu, 2012).

Şekil 3'de de görüldüğü gibi 1 kişiyi işe almak için en fazla adayla Türkiye'de görüşülmektedir. Bu bir anlamda işe alımla ilgili kaynakların etkin kullanılmadığını, doğru strateji belirlenmediğini de göstermektedir. İşe alım öncesinde planlamanın çok iyi yapılması, hedef kitlenin çok iyi belirlenmesi gerekmektedir. İşe alım görüşmeleri de bu hedef kitleye yönelik yapılmalıdır. İşveren markasında önemli olan çok sayıda başvuru almak değil yetenekli kişilerin başvurusunu almaktır, olabildiğince çok kişi ile görüşmek değil hedefe uygun adaylarla görüşmektir. Bu konuda verilebilecek iyi örneklerden bir tanesi Google işletmesine aittir. Ücretsiz yemek, yerinde tıbbi bakım, çamaşırhane hizmetleri vb. hizmetler Google'1 çekici bir işveren konumuna getirmektedir ve küresel anlamda yaklaşık 10.000 işgörenden sadece ABD'de günde 1.300 işgören Google'a iş başvurusunda bulunmaktadır (Gehrels ve Looij, 2011:44). Fakat bu adaylardan hedefe en uygun olanları ile mülakat yapılmaktadır. Unutulmamalıdır ki, işletmenin harekete geçirici ve itici gücünü oluşturacak nitelikli insanların dikkatini ve ilgisini işletmeye çekmek, onların başvurusunu sağlamak çok önemli bir adımdır (Karacan ve Akpınar, 2011, s. 135).

\section{Sonuç ve Öneriler}

Küreselleşmenin işletmeler üzerinde oluşturduğu etki ulusal ve uluslararası pazarda var olan sınırları genişletmekte veya kaldırmakta işletmeleri en baştan rekabete zorlamaktadır. $\mathrm{Bu}$ rekabeti sürdürmek de sadece teknik donanımla, teknolojiyi kullanabilme becerisi ile mümkün olamamaktadır. Tüm kaynak ve süreçlerin hemen hemen tamamını yöneten insan faktörü ve insan kaynakları yönetimi kavramları ön plana çıkmaktadır. Ellerinde bulundurdukları ve işletmeye çekmeyi planladıkları insan kaynakları ile üstünlük elde etmek isteyen işletmeler işveren markası yönetimi süreçlerini işletmelerine entegre etmeleri, stratejik yönetim unsuru haline getirmeleri gerekliliği ortaya çıkmaktadır. 
Özellikle 1980'li yılların ortalarından itibaren gelişmiş ülkelerde işgücünün bir pazar olarak algılanması daha da ön plana çıktığı, geleneksel olarak adayların satıcı, işletmelerin alıcı oldukları işgücü pazarında roller tersine dönmeye başlamaktadır. Bilginin en önemli yetenek haline geldiği, müşterilerin yetenekleri ödüllendirdiği, farklı nesillerin bir arada bulunduğu ve işyerine sadakat gibi kavramların zayıfladığı bir yetenek pazarında pazarlama odaklı bir yetenek stratejisi geliştirmenin önemi de artmıştır (Erdemir, 2007).

Bir ürün veya kurumun marka haline getirilmek istenmesinin temel sebebi, diğer ürün veya kurumlardan ayırt edilmesinin sağlanmasıdır. Bir işverenin işletmesini marka haline getirmek istemesinin sebebi, rakiplerinden farklılaşmasının sağlanmasıdır. Seçme şansı olan yetenekli bireyler, ürün veya kurum seçen tüketiciler gibi davranmaktadır ve işletmenin işveren olarak markalaşması adayları etkileyip kazanmanın, mevcut yetenekleri de elde tutmanın bir yolu durumuna gelmektedir.

İşe alım öncesi dönem uygulamalarının amacı da, işletme kültürüne uygun adayları işletmeye katmak ve bu sayede sürdürülebilir rekabet avantajı yakalamaktır. Güçlü teknik ve analitik özelliklere sahip potansiyel işgörenleri bulmak ve bu adayların oluşturduğu havuz içerisinde rekabete girmek ise giderek zorlaşmaktadır. Yurt dişında çok daha uzun yıllardır gerek uygulamada gerekse akademik çalışmalarda işveren markası konusu işlerliğini korumaktadır. Türkiye'de ise işveren markası çalışmaları son yıllarda hız kazanmış durumdadır.

$\mathrm{Bu}$ güne kadar yapılan çalışmalar ve başarılı şirketlerin sonuçları da göstermektedir ki işletmelerini işveren olarak markalaşmak için bir değer, ürün ve hizmet gibi düşünen, stratejik planlarına işveren markası yönetimini dahil eden işletmeler işe alım öncesi dönem ve işgören seçimi döneminde çok daha aktif olmaktadır. Bu nedenle, hangi sektörde olursa olsun işe alım öncesi dönemden itibaren işletmelerin işgücü pazarında ayakta kalabilmeleri, varlıklarını devam ettirebilmeleri ve üstün rekabet avantajı elde edebilmeleri için işveren markası konusuna gereken ilgiyi göstermesi ve işletme stratejilerinde yer vermeleri gerektiği söylenebilir.

$\mathrm{Bu}$ çalışmada işveren markası bileşenlerinden ve insan kaynakları fonksiyonlarından işe alım öncesi dönem ve işgören seçimi ele alınmıştır. Bundan sonraki araştırmalarda diğer insan kaynakları uygulamaları işveren markası yönetimi açısından incelenebilir. Çeşitli sektörlerin işe alım öncesi dönem ve işgören seçiminde gerçekleştirdikleri işveren markasına yönelik uygulamaları tespit edilerek karşıllaştırmalar yapılabilir.

$\mathrm{Bu}$ çalışmada, işe alım öncesi dönem ve işgören seçimi işveren markası yönetimi bağlamında kavramsal olarak analiz edilmeye çalışılmıştır. Gelecek araştırmalarda, araştırmacıların konuyu deneysel olarak ele almalarının işe alım öncesi dönem ve işgören seçimi konusunda önemli katkılar sağlayabileceği düşünülmektedir. 


\section{KAYNAKÇA}

Alnıaçık, E ve Ümit, A. (2012). "Identifying Dimensions of Attractiveness in Employer Branding: Effects of Age, Gender and Current Employment Status", ProcediaSocial and Behavioral Sciences, 58: 1336-1343.

Ambler, T. ve Barrow, S. (1996). "The Employer Brand", Journal of Brand Management, 4(3): 185-206.

Bach, S. (2005). Managing Human Resources: Personnel Management in Transition, Blackwell Publishing, Malden.

Backhaus, K. ve Tikoo, S. (2004). "Conceptualizing and Researching Employer Branding." Career Development International 9(5): 501-517.

Baş, T. (2011). İşveren Markası Yüksek Nitelikli Çalışanları Çekmenin ve Elde Tutmanın Anahtarı. İstanbul, Optimist Yayınları.

Baum, M. ve Rüdiger, K. (2013). "How to attract applicants in the Atlantic versus the Asia-Pacific region? A cross-national analysis on China, India, Germany, and Hungary." Journal of Worl Business, 48: 175-185.

Berthon, P., M. Ewing ve Hah, L. L. (2005). "Captivating Company: Dimensions of Attractiveness in Employer Branding." International Journal of Advertising The Quarterly Review of Marketing Communications 24 (2): 151-173.

Bloomberg Businessweek Türkiye, 2010

Bodderas, M., Cachelin, J. L. ve Maas, P. (2010). "Integrating Marketing And Human Resources: The Link Between Employee's Job Satisfaction, İdentification With The Company And Employer Branding", Marketıng, Strategy, Economics, Operations \& Human Resources: Insights on Service Activities, the 11th Internatıonal Research Seminar in Service Management, La Londe Les Maures, France.

Duc/To, N.T. (2013). Employer Branding for SMEs: Attracting Graduating Students in IT Industry. Karjaani University of Applied Sciences Heilbronn University of Applied Sciences School of Business. Degree Program in Business Management.

Erdemir, E. (2007). Işse Almada Aday Odaklılık: Kavramsal Çerçeve ve Ölçek Geliştirme, Eskişehir Anadolu Üniversitesi, Sosyal Bilimler Enstitüsü, Yayımlanmamış Doktora Tezi, Eskişehir.

Gehrels, S.A. ve Looij, J. (2011). "Employer Branding: a New Approach for the Hospitality Industry", Research in Hospitality Management, 1(1): 43-52.

Gümüş, B. (2005). İ̧s Analizinin İnsan Kaynakları Yönetimi Açısından Önemi ve Diğer Insan Kaynakları Fonksiyonları ile Olan Iliş̧kisi, Eskişehir Anadolu Üniversitesi, Sosyal Bilimler Enstitüsü, Yüksek Lisans Tezi, Eskişehir.

Gürüz, D. ve Yaylacı, G. Ö. (2004). Iletişimci Gözüyle İnsan Kaynakları Yönetimi. İstanbul, Kapital Medya Hizmetleri. 
İşe Alım Raporu 2012 (2012). http://documents.tips/documents/2012-ise-alimarastirma-raporu.html 2012 İşe Alım Araştırma Raporu, erişim tarihi, 07.10.2015.

Kapoor, V. (2010). "Employer Branding: A Study of Its Relevance in India", Journal of Brand Management 27(1 ve 2): 51-75.

Karacan, E. ve Akpınar, A. T. (2011). "Çalışanların İşyerini Seçme Kararını etkileyen Faktörlerin Önem Derecesini Belirlemeye Yönelik Bir Araştırma: Kocaeli Örneği." Kocaeli Üniversitesi Sosyal Bilimler Enstitüsü Dergisi 21(1): 132-149.

Katoen, RJ. ve Macioschek, A. (2007) Employer Branding and Talent - Relationship Management - Improving the Organizational Recruitment Approach, Umea University, Master Thesis.

Kimpakorn, N. ve Tocquer, G. (2009). "Employees' commitment to brands in the service sector: Luxury hotel chains in Thailand", Journal of Brand Management, 16: $532-544$.

Lievens, F. ve Highhouse, S. (2003). "The Relation of Instrumental and Symbolic Attributes to a Company's Attractiveness as an Employer." Personel Psychology 53: $75-102$.

Mangold, W. G. ve Miles, S. J. (2007). "The Employee Brand: Is Yours an all-star?" Business Horizons 50: 423-433.

Martin, G., P. Beaumont, vd. (2005). "Branding: A New Performance Discourse for HR?" European Management Journal 23(1): 76-88.

Melin, E. (2005). Employer Branding Likenesses and Differences between External and Internal Employer Brand Images. Business Administration and Social Sciences Division of Industrial Marketing and e-Commerce. Sweden, Lulea University of Technology. Master: 92.

Mengi, Z. (2012). İş Arama Sürecinde Sosyal Medya Kullanımına Dikkat. Hürriyet İK. Hürriyet Gazetecilik ve Matbaacılık A.Ş., Hürriyet Gazetesi. 23 Eylül: 7

Minchington, B. (2010 a). "Why Would Someone Want to Work for You?" Journal of Corporate Recruiting Leadership October: 10-14.

Minchington, B. (2010 b). "Employer Branding Needs Good Leadership" HR Future September: $12-13$.

Minchington, B. (2014). "Employer Brand International 2014”, Employer Branding Global Trends Survey Report by Brett Minchington.

Oğuz, N. (2012). İşveren Markası ve Kabiliyeti Çekme Üzerine Etkisi. İşletme Ana Bilim Dalı. İzmir, Ege Üniversitesi Sosyal Bilimler Enstitüsü, Yayımlanmamış Yüksek Lisans Tezi.

Ong, L.D. (2011). "Employer Branding and its Influence on Potential Job Applicants", Australian Journal of Basic and Applied Sciences, 5(9): 1088-1092.

Öksüz, B. (2012). “İşveren Markası Yönetimi Sürecinde İletişimin Önemi”, http://josc.selcuk.edu.tr/article/download/1075000051/1075000048 (erişim tarihi, 17.10.2015). 
Ören, K. ve Yüksel, H. (2012). "Marka İşveren veya İşveren Markası Kavramı: Bu Kavramın İnsan Kaynakları Yönetimi Bağlamında ve İşçi Devir Hızı Kapsamında Değerlendirilmesi”, Kamu-İs, 12 (3):31-52.

Pelit, E. ve Öztürk, Y. (2010). “Otel İşletmeleri İşgörenlerinin İş Doyum Düzeyleri: Sayfiye ve Şehir Otel İşletmeleri İşgörenleri Üzerinde Bir Araştırma." İşletme Araştırmaları Dergisi, 2/1:43-72.

Pelit, E., Öztürk, Y., Arslantürk, Y. (2011). "The Effects of Employee Empowerment on Employee Job Satisfaction A study on hotels in Turkey", International Journal of Contemporary Hospitality Management, Vol. 23 No. 6, 2011 pp. 784802.

Pelit, E. (2015). “Turizm İşletmelerinde İnsan Kaynakları Yönetiminin Önemi” İçinde: Turizm Isşletmelerinde İnsan Kaynakları Yönetimi. Elbeyi Pelit (Ed.), (s.61-130). Grafiker Yayınları, Ankara.

Randstad Award (2012). Most Attractive Employer India Country Report.

Rosethorn, H. (2009). Methodology A Concept in Action, The Employer Brand: Keeping Faith With The Deal, Gower, Burlington.

Sakarya, A. (2012). "Öğrencilerin Gözü Bu İşletmelerde" Bloomberg Businessweek Türkiye 25 Mart - 31 Mart: 52-63.

Sayılar, Y. (2004). "İnsan Kaynakları Yönetimi Alanında Kuram ve Araştırmanın Gelişimi: Stratejik olan ve Olmayan Perspektiflerden Bir İnceleme." Yönetim Bilimleri Dergisi, 3(1): 45-64.

Sullivan J. (2004). "The 8 Elements of a Successful Employment Brand", http://www.ere.net/2004/02/23/the-8-elements-of-a-successful-employmentbrand/, (erişim tarihi, 14.07.2015).

Walker, P. ve Higgins, A. (2007). Employer Branding: a no nonsense Aproach, London: Guide CIPD. 


\title{
Pre-Recruitment Period and Employee Selection in Employer Brand Management Process: A Conceptual Evaluation
}

\author{
Ebru GÖZEN \\ Ela Quality Resort Hotel \\ Antalya, Turkey \\ ebrugozen2306@gmail.com
}

\section{Extensive Summary}

Nowadays it's critical important for the companies having resources that are difficult to counterfeit, in the other words equipped labor, retention and use them according to company objectives. So, companies that want to achieve competitive advantage and make it sustainable, must give required importance to employer brand concept in pre-recruitment practices. Increasingly, companies accept the employees as a majör source to achieve the sustainable competitive advantage in the global competition. In this study, pre- recruitment and employee selection process is handled between the many human resources functions. The reason to handle this process is prerecruitment and employee selection process is the basis of the other human resources practices. The functions of human resources in the pre- recruitment period can be sorted as follows;

- Job analysis,

- Human resources planning,

- $\quad$ Getting the job applications and

- Human resources selection.

Companies must give the importance for being a brand as an employer to attract the qualified candidates or differentiate from competitors that making same or similar business when all these activities are performed. Changes in job ads, videos that introduce the company, creation of company career sites, career days that held at the high school and universities, taking part little more in a social media each day and looking for employee by these channels are the employer brand practices in preemployment period. In fact, companies have a god or bad employer brand. Some of them are aware of it and some of them are not. The important thing is to manage it correctly. In terms of employer brand it should be noted that employer brand management is not employment marketing. Employer brand management is the overall project which human resources department focuses on human rather than source. The aim of employer brand is not get much application as possible, it is to get the right ones. Although human resources department is responsible for recruitment, it is a matter of debate which department / departments is/are responsible for employer brand. As a 
result of Employer Brand International which department / departments is/are responsible for employer brand management is shown in Figure 1.

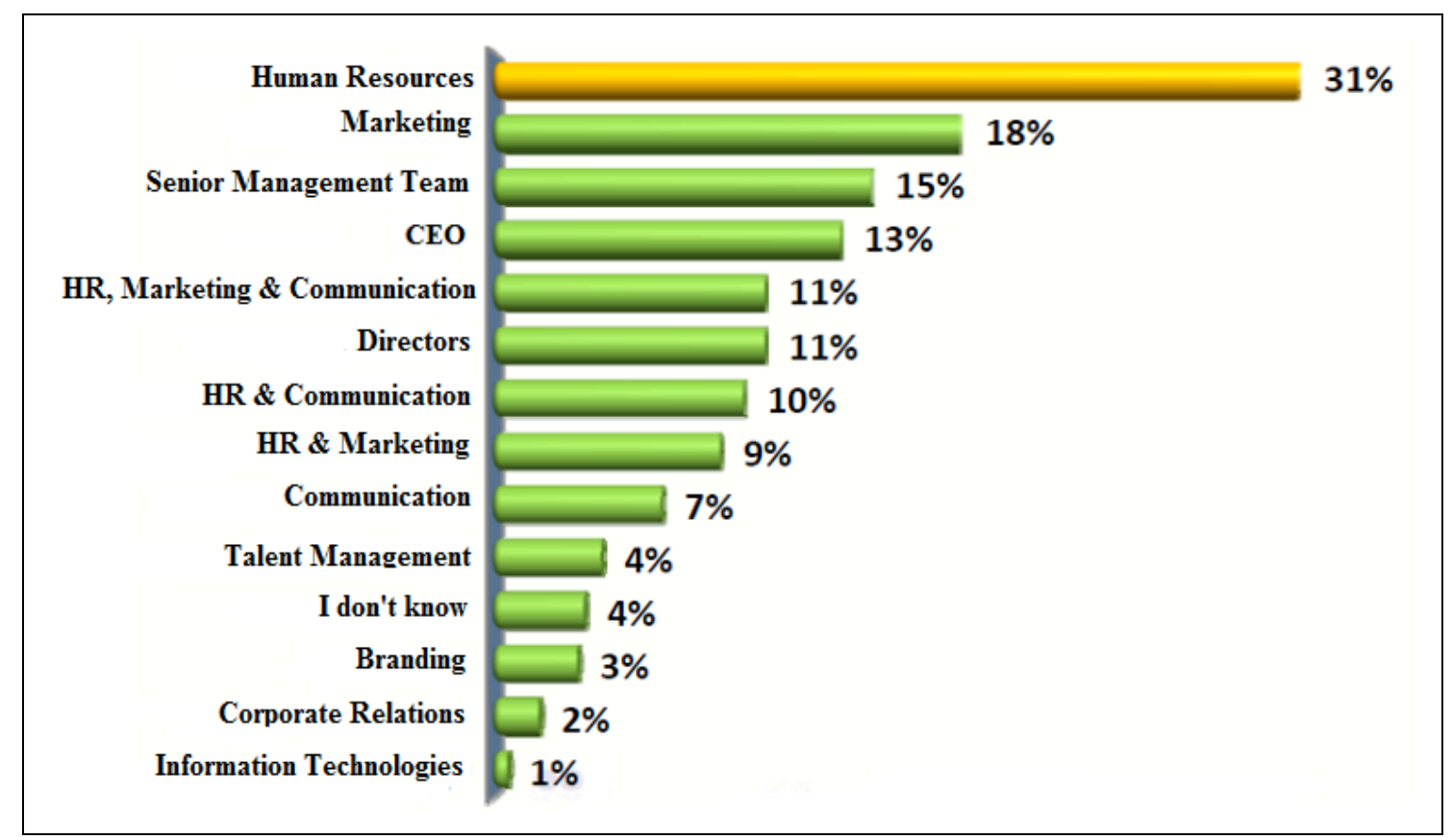

Figure 1: Department / Departments Responsible for Employer Branding (Minchington, 2014).

It's said that human resources must be strategical component of the companies for a long time. It's seen that HR is the main responsible department for employer brand in Figure 1.

Employer brand concept can be analyzed three stages in terms of human resources management (Backhous ve Tikoo, 2004, s. 502);

1. Company develops concrete value proposition and market it to potential employees, employment agencies, stakeholders and consultants etc. following the development of value proposition.

2. External marketing of employer branding is designed to attract target population also to support and develop corporate brands.

3. Internal marketing is the third step of employer brand. The aim of this step to develop the labor by adhering to the whole organizational values and goals.

But, unfortunately, many of the companies are still ignoring these stages. Dr. John Sullivan who is recognized as one of the world's leading HR strategist points that the companies are unaware of what the employer brand is although Turkey has a serious qualified HR potential in one of his articles published in 2006. In this case, it's seen that is not paid sufficient attention to employer brand practices. Whereas, company's impressions about its employer image in the pre-recruitment period are strong indicators to attract the applicants to the company. Employer brand managers build and manage employer brand in professional companies. In this study, one of the components of employer brand and human resources pre-recruitment period and employee selection is handled. In the future researchs other HR practices can be examined in terms of employer brand management. Employer branding practices about pre-recruitment 
period and employee selection can be determined and comparisons can be made in various sectors. In this study, pre-recruitment period and employee selection has been tried to analyze in the context of employer brand management. In future researchs it is expected to provide significant contributions about pre-recruitment period and employee selection if researchers handle the subject experimental. 